\title{
Antagonism of Thyroid Hormone Action by Amiodarone in Rat Pituitary Tumor Cells
}

Mark F. Norman and Thomas N. Lavin

Metabolic Research Unit, University of California, San Francisco, California 94143

\begin{abstract}
A thyroid hormone antagonist has not been previously described. A number of thyroid hormone analogues have been shown to compete with $\left.{ }^{125} I\right]$ triiodothyronine $\left.\left({ }^{125} \mathrm{I}\right] \mathrm{T}_{3}\right)$ for binding to the intranuclear thyroid hormone receptor and to have agonist activity proportional to their affinities for the receptors. We report that the benzofuran amiodarone acts as a competitive antagonist to thyroid hormone action as defined by its dose-dependent ability to $(a)$ bind to the thyroid hormone receptor and $(b)$ inhibit $T_{3}$-induced increases in growth hormone mRNA levels in a cultured rat pituitary cell line, GC cells. Like $\mathrm{T}_{3}$ itself, amiodarone also decreases transport of [ $\left.{ }^{125} \mathrm{I}\right] \mathrm{T}_{3}$ across GC cell membranes. An analysis of the amiodarone structure suggests that this compound has certain similarities to $T_{3}$. These findings hold promise for the development of other thyroid hormone antagonists for clinical use and for understanding thyroid hormone action.
\end{abstract}

\section{Introduction}

Most cell receptors for small organic molecules have a developed pharmacology of agents that act as agonists or antagonists. For example, suitable antagonists can block the actions of dopaminergic, alpha and beta adrenergic, and cholinergic agonists (1). Antagonists have been described that interact with the mineralocorticoid, glucocorticoid, estrogen, and progesterone receptors (1). It is surprising, however, despite extensive structure activity studies conducted over the past 20 years $(2,3)$, no antagonist for thyroid hormone receptor action has been identified.

Amiodarone is a benzofuran (2-butyl-3-[3,5-diiodo-4-( $\beta$ diethylaminoethoxy)-benzoyl]benzofuran) widely prescribed for the treatment of ventricular and supraventricular arrhythmias $(4,5)$. Chronic administration of amiodarone has been associated with both hyper- and hypothyroid-like side effects. The drug has also been reported to cause changes in the concentrations of serum thyroxine $\left(T_{4}\right)$ and triiodothyronine $\left(T_{3}\right)$ levels, which have been attributed to an inhibition of peripheral $\mathrm{T}_{4}$ monodeiodination, and to iodine-induced changes in glandular hormonogenesis $(6,7)$. However, cases of clinical hypothyroidism have occurred, often with mildly elevated thyroid-stimulating hormone (TSH) and normal $\mathrm{T}_{4}$ and $\mathrm{T}_{3}$ levels, and in vitro studies have suggested an amiodarone-induced

Address reprint requests to Dr. Lavin, Metabolism Research Unit, 671 HSE, University of California, San Francisco, CA 94143-0516.

Received for publication 30 October 1987 and in revised form 14 July 1988

J. Clin. Invest.

(C) The American Society for Clinical Investigation, Inc.

0021-9738/89/01/0306/08 \$2.00

Volume 83, January 1989, 306-313 increase in pituitary TSH release, together with a decrease in $\left[{ }^{125} \mathrm{I}\right] \mathrm{T}_{3}$ binding to pituitary nuclei (8); these observations raise the suspicion that amiodarone could act as a thyroid hormone antagonist at the receptor level.

In this study we report that amiodarone fulfills the criteria of a thyroid hormone antagonist. The drug behaves as a competitive inhibitor of $\mathrm{T}_{3}$ binding to solubilized thyroid hormone receptors, and it blocks both receptor binding and the biological effect of thyroid hormone when administered to hormoneresponsive cells in culture.

\section{Methods}

Cell culture. GC cells were obtained from the cell culture facility, University of California at San Francisco (UCSF). They were plated at $2-4 \times 10^{6}$ cells $/ 100 \mathrm{~mm}$ tissue culture dish (Falcon Labware, Oxnard, CA) and were maintained at $37^{\circ} \mathrm{C}, 95 \%$ air, $5 \% \mathrm{CO}_{2}$, in DME $\mathrm{H}-21$ medium containing $10 \%$ fetal calf serum (FCS; J. R. Scientific; Woodland, CA), $100 \mathrm{U} / \mathrm{ml}$ penicillin and streptomycin, and $2 \mathrm{mM}$ glutamine.

Removal of thyroid hormones from FCS. Thyroid hormones were removed from serum with AG 1-X8 ion exchange resin (Bio-Rad Laboratories, Richmond, CA) as described (9). Before treatment, $T_{4}$ and $T_{3}$ concentrations in whole serum were $1.9 \times 10^{-7} \mathrm{M}$ and 1.9 $\times 10^{-9} \mathrm{M}$, respectively. In $100 \%$ thyroid hormone-depleted (stripped) serum they were $1.7 \times 10^{-8} \mathrm{M}$ and nondetectable $(<300 \mathrm{pM})$. Actual concentrations in $2 \%$ media were therefore $1 / 50$ of these values.

Preparation of solubilized $T_{3}$ nuclear receptors. Rat liver nuclear receptors were prepared according to Apriletti et al. (10). Solubilized nuclear receptors from whole rat brain were prepared according to Schwartz and Oppenheimer (11) except that receptors were solubilized with $0.4 \mathrm{M} \mathrm{KCl}$. Livers and brains were from euthyroid rats, which were obtained from Rockland, Inc. (Gilbertsville, PA). Solubilized receptors from GC cells were prepared as follows: confluent $150-\mathrm{cm}^{2}$ culture plates were rinsed for 5 min with PBS $\left(37^{\circ} \mathrm{C}\right)$, then scraped with a rubber policeman in $5 \mathrm{ml} \mathrm{PBS}\left(4^{\circ} \mathrm{C}\right)$. The $1,000 \mathrm{~g}$ cell pellet was suspended in $10 \mathrm{ml}$ solution $\mathrm{A}$, on ice [ $20 \mathrm{mM} \mathrm{KPO}_{4}, \mathrm{pH}=7.6 ; 4 \mathrm{mM}$ EGTA; $4 \mathrm{mM} \mathrm{MgCl}_{2} ; 0.25 \mathrm{M}$ sucrose; $0.5 \% \mathrm{NP}-40$; $0.5 \mathrm{mM}$ PMSF; $0.1 \%$ monothioglycerol (MTG) $)^{1}$. Cells sat on ice for $3 \mathrm{~min}$, followed by a second spin. The resulting cell lysate was washed with solution $A$ minus NP-40, pelleted again, and resuspended in $10 \mathrm{ml}$ of solution $B$ (20 $\mathrm{mM} \mathrm{KPO}_{4}, \mathrm{pH}=7.2 ; 10 \mathrm{mM}$ EDTA; $2 \mathrm{mM} \mathrm{MgCl}$ ). The nuclei were gently mixed and allowed to sit at $4^{\circ} \mathrm{C}$ for $30 \mathrm{~min}$. This suspension was then centrifuged $(300 \mathrm{~g}, 10 \mathrm{~min})$, and the resulting chromatin pellet was washed twice in $10 \mathrm{ml}$ of solution $\mathrm{C}\left(10 \mathrm{mM} \mathrm{KPO}_{4}, \mathrm{pH}\right.$

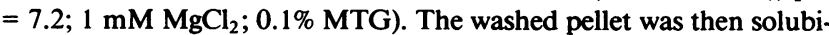
lized in $2 \mathrm{ml}$ of solution $\mathrm{D}(10 \mathrm{mM}$ Tris; $1 \mathrm{mM} \mathrm{MgCl} 2 ; 0.5 \mathrm{mM}$ EDTA; $400 \mathrm{mM} \mathrm{KCl} ; 10 \%$ glycerol; $0.1 \% \mathrm{MTG} ; \mathrm{pH}=7.6)$. The chromatin was then sonicated in this solution (30 1-s pulses). After a 30-min incubation on ice, polyethyleneimine (PEI) was added to a final concentration of $0.01 \%$ and the solution stirred gently for $5 \mathrm{~min}$. Following centrifugation at $15,000 \mathrm{~g}$ for $15 \mathrm{~min}$ the supernatant was adjusted to $3 \%$ PEG, $0.02 \%$ PEI, and $20 \mathrm{mM} \mathrm{KPO}_{4}$. After $20 \mathrm{~min}$ on ice this

1. Abbreviations used in this paper: MTG, monothioglycerol; PEI, polyethyleneimine. 
suspension was centrifuged again $(15,000 \mathrm{~g}, 30 \mathrm{~min})$ and aliquots were frozen in liquid $\mathrm{N}_{2}$ and stored at $-70^{\circ} \mathrm{C}$. Treatment with PEI removed any contaminating DNA. Yield for $900 \times 10^{6}$ cells $=7.5 \mathrm{pmol}$; sp act, $3.1 \mathrm{pmol} / \mathrm{mg}$ protein $=5,000$ sites $/$ cell.

In vitro binding assays. $\left[{ }^{125} \mathrm{I}\right] \mathrm{T}_{3}$ and thyroid hormone receptor preparations were incubated with varying concentrations of nonradioactive $\mathrm{T}_{3}$ or amiodarone for $18 \mathrm{~h}$ at $4^{\circ} \mathrm{C}$ in a buffer consisting of 20 $\mathrm{mM} \mathrm{KPO}_{4}, 0.5 \mathrm{mM}$ EDTA, $1 \mathrm{mM} \mathrm{MgCl}, 400 \mathrm{mM} \mathrm{KCl}, 8 \%$ glycerol, and $0.1 \%$ MTG. Bound and free $\left[{ }^{125} \mathrm{I}\right] \mathrm{T}_{3}$ were separated with G-25 Sephadex. Receptor concentrations were $150-300 \mathrm{pM}$. L- $\mathrm{T}_{3}$ was from Aldrich Chemicals (Milwaukee, WI). A 1-mM stock was prepared in $\mathrm{MeOH}$ containing $1 \% \mathrm{NH}_{4} \mathrm{OH}$. This was diluted in $0.1 \mathrm{mM} \mathrm{NaOH}$ and added directly to binding and culture assays. Amiodarone- $\mathrm{HCl}$ was obtained in liquid form (Cordarone; Labaz, France) or as a purified powder (Sanofi Chemicals, Montpellier, France). The liquid form was supplied at $73 \mathrm{mM}$ in a vehicle consisting of (vol/vol) $88.8 \% \mathrm{H}_{2} \mathrm{O}$, 9.3\% Tween $80,1.9 \%$ benzyl alcohol. The powder was prepared fresh at $14 \mathrm{mM}$ in EtOH:10 mM HCl (1:1). Dilutions from both solutions were prepared in $1 \mathrm{mM} \mathrm{HCl}$. Control experiments were carried out in the presence of appropriate vehicles, which had no effect on binding reactions. Preliminary experiments suggested that the powdered form, prepared and diluted as described, did not affect intact, cultured GC cells in a manner identical to the liquid form, probably because of solubility problems. For this reason, all data reported herein are based upon experiments utilizing the liquid stock. $L-\left[{ }^{125} \mathrm{I}\right] \mathrm{T}_{3}$ was from New England Nuclear (Boston, MA; NEX-110X: 2,200 Ci/mmol).

Binding of $\left[{ }^{125} I\right] T_{3}$ to intact $G C$ cells and cell fractions. 2 million cells were plated per well of 6-well tissue culture plates (Falcon; 9.3 $\mathrm{cm}^{2} /$ well $)$ in $3 \mathrm{ml}$ of media. After $18 \mathrm{~h}$ cells were rinsed with PBS $(1 \mathrm{ml}$, $10 \mathrm{~min}, 37^{\circ} \mathrm{C}$ ) and incubated for $4 \mathrm{~h}$ in DME containing $10 \%$ serum substitute solution (12) and 2\% stripped FCS. For competition assays, cells were incubated in $1 \mathrm{ml}$ of stripped media containing $300 \mathrm{pM}$ $\left[{ }^{125} \mathrm{I}\right] \mathrm{T}_{3}$ and various doses of amiodarone. Incubations were carried out at $37^{\circ} \mathrm{C}$ on a tilt table. After $3 \mathrm{~h}$, during which time equilibrium was established, cells were washed thoroughly in PBS, and whole-cell radioactivity was determined. Cell nuclei were then prepared by lysis in situ and specific nuclear binding determined according to established methods for pituitary tumor cells (13). Binding in each nuclear pellet was normalized to DNA content $(14) .\left[{ }^{125} \mathrm{I}\right] \mathrm{T}_{3}$ radioactivity was also determined in the supernatant of the nuclear pellet. For the purposes of this study the supernatant, which contained cytosol and lysed cellular membranes, was termed cytosol. In separate experiments, GC cells were cultured as described except in the presence of $1.5 \mathrm{nM}\left[{ }^{125} \mathrm{I}\right] \mathrm{T}_{3}$. Under these conditions, binding capacity was $\sim 85 \mathrm{fmol} / 100 \mu \mathrm{g}$ DNA. Nuclear radioactivity was $5 \%$ or less of total cellular radioactivity.

Analysis of receptor binding parameters. Binding data were analyzed with the Scatfit and Allfit computer programs. These programs perform nonlinear, least squares model fitting utilizing untransformed data by sequential iteration of binding parameters and generate $K_{\mathrm{d}}$, maximum bound $\left(B_{\max }\right), \mathrm{EC}_{50}$, and pseudo-Hill slope constants $(b)$. Slopes greater than unity indicate positive cooperativity or nonequilibrium conditions. Slopes less than unity indicate heterogeneity of binding sites and/or negative cooperativity. Slopes indistinguishable from one are consistent with a single site, mass action binding model (15). The ability of amiodarone to compete with $T_{3}$ for binding to the thyroid hormone receptor was assessed by comparison of $K_{d}$ and $\mathrm{EC}_{50}$ values generated by the Scatfit and Allfit programs, respectively $(15,16)$.

Preparation and quantitation of messenger RNA. After plating and attachment (12-18 h), GC cells were cultured for 2-4 d in $20 \mathrm{ml}$ of DME containing $10 \%$ serum substitute solution plus $2 \%$ stripped serum (9). Media were replaced after the second day of culture. It has been demonstrated previously $(17,18)$ that $2-4 \mathrm{~d}$ of culture under "hypothyroid" conditions ("deinduction") produce baseline levels of rGH mRNA in pituitary tumor cells. In one set of experiments, cells were deinduced for $4 \mathrm{~d}$, then cultured for an additional $2 \mathrm{~d}$ in stripped media containing: (a) $300 \mathrm{pM} \mathrm{T}$ plus varying concentrations of amiodarone, or (b) no additional treatment (Fig. 4). In a second set of experiments, they were deinduced for $48 \mathrm{~h}$, then cultured for an additional $48 \mathrm{~h}$ in stripped media containing $3.2 \mu \mathrm{M}$ amiodarone plus varying concentrations of $T_{3}$ (Fig. 5). Total cytoplasmic (19) or total cellular (20) mRNA were prepared as described. The amount of rGH message present in aliquots of GC cell cytoplasm was determined by Northern hybridization using glyoxylated RNA (21). Equal amounts of cytoplasmic RNA were examined per lane ( 15 or $20 \mu \mathrm{g})$. HeLa cell RNA also was tested as a control for specificity and background binding. The rGH message was detected by hybridization with the $0.8 \mathrm{~kb}$ pRGH-1 rat growth hormone cDNA (22). Some blots were also probed with a $1.6 \mathrm{~kb}$ Xho I fragment of the pHF1 human $\gamma$-actin gene (23). Both probes were labeled by nick translation with [ ${ }^{32} \mathrm{P}$ ]dCTP (Amersham Corp., Arlington Heights, IL) to $3-5 \times 10^{8} \mathrm{cpm} / \mu \mathrm{g}$ (24). Hybridizations were carried out for $18-48 \mathrm{~h}$ at $42^{\circ} \mathrm{C}$. Blots were autoradiographed with Kodak XAR-2 film using Cronex Lightning Plus intensifying screens (E. I. DuPont de Nemours Co., Wilmington, DE), and then quantitative densitometry was performed with a Zeineh soft laser scanning densitometer. Alternatively, filter strips were dissolved in Filtron-X (National Diagnostics, Inc., Somerville, NJ) and counted.

Amiodarone and $T_{3}$ were added separately to each $100-\mathrm{mm}$ culture dish ( $250 \mu \mathrm{l}$ of each drug or vehicle in a total volume of $20 \mathrm{ml})$. It was essential that this procedure be followed: amiodarone was ineffective when added in advance to a large volume of serum-containing media in a glass beaker.

Computer modeling of $T_{3}$ and amiodarone structures. Computer modeling was performed by Teri Klein and George Seibel at the Computer Graphics Lab, UCSF. The compounds were modeled in extended conformation using standard geometries. Coordinates were displayed and manipulated in real time with the MIDAS program on an Evans and Sutherland graphics system. Very small torsion angle adjustments were required to superimpose the molecular structures.

\section{Results}

The characteristics of binding by $T_{3}$ to its nuclear receptor were first determined using crude preparations of $\mathrm{KCl}$-solubilized rat liver nuclei. In these assays, $T_{3}$ bound to a single class of sites with high affinity (weighted mean of six determinations $\left(K_{\mathrm{d}}=359 \mathrm{pM}\right.$; range $\left.189-630 \mathrm{pM}\right)$. The $K_{\mathrm{d}}$ value of $359 \mathrm{pM}$ was derived from nonlinear least-squares regression analysis of experimental data $(15,16)$ and was used as an initial estimate of receptor affinity in subsequent analyses of binding assays. Affinities were similar for receptors from solubilized GC cell nuclei and from cultured GC cells (560 and 470 pM, respectively). The results for solubilized hepatic receptors are similar to those reported previously $(25,26)$.

In a variety of solubilized receptor preparations, amiodarone competed with $T_{3}$ for binding to a single class of sites in a dose-dependent fashion at concentrations from 0.1 to $100 \mathrm{mM}$ (Fig. $1 \mathrm{a}$ ). For rat liver-derived receptor, the $50 \%$ inhibition (EC $\mathrm{ES}_{50}$ ) occurred at $3 \mu \mathrm{M}$ amiodarone, and $80 \%$ inhibition was at $50 \mu \mathrm{M}$. Amiodarone rarely produced $>80 \%$ inhibition of $\left[{ }^{125} \mathrm{I}\right] \mathrm{T}_{3}$ binding in these preparations. This is probably due to the poor solubility of the drug in high ionic strength buffers (27), which results in precipitates at higher concentrations. The calculated affinity of the receptor for amiodarone in this experiment expressed as the $K_{\mathrm{d}}$ was $1.4 \mu \mathrm{M}$. Amiodarone also competed with $\left[{ }^{125} \mathrm{I}\right] \mathrm{T}_{3}$ for binding to solubilized receptors from pituitary tumor cells of the GC cell line with a $K_{d}$ of 1.6 $\mu \mathrm{M}$. The affinity for receptors from rat brain was somewhat less $\left(K_{\mathrm{d}}=13.7 \mu \mathrm{M} ; n=3\right.$; see Table I).

The competitive nature of amiodarone binding was further investigated by examining the effect of $10 \mu \mathrm{M}$ amiodarone on the binding of increasing doses of $\left[{ }^{125} \mathrm{I}\right] \mathrm{T}_{3}$ to its receptor 


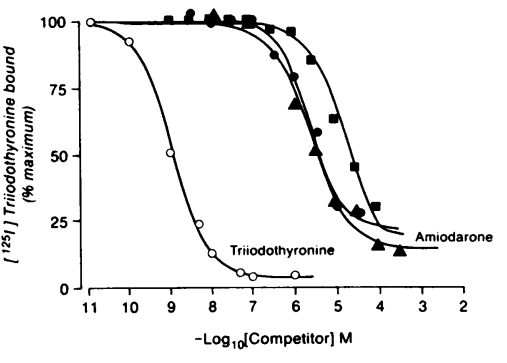

Figure 1. Competition by unlabeled $\mathrm{L}-\mathrm{T}_{3}$ and amiodarone for binding of $L-\left[{ }^{125} I\right] T_{3}$ to rat nuclear thyroid hormone receptors solubilized from various tissues. Pictured are competition curves for $T_{3}$ in liver receptors (open circles); and for amiodar-

one in liver (closed circles), whole brain (closed boxes), and GC cell receptors (closed triangles). The affinity $\left(K_{d}\right)$ for $T_{3}$ in liver nuclear receptors was $3.7 \times 10^{-10} \mathrm{M}$. In the individual experiments shown, affinities for amiodarone were $1.4,13.7$, and $2.9 \mu \mathrm{M}$ in solubilized receptors from rat liver, brain, and pituitary tumor (GC) cells, respectively. $[r]=160-280 \mathrm{pM} .\left[{ }^{125} \mathrm{I}\right] \mathrm{T}_{3}=100-200 \mathrm{pM}$.

(Fig. $2 A$ ). Computer modeling of these curves revealed an amiodarone $K_{\mathrm{i}}$ of $9.3 \mu \mathrm{M}$ for a single class of sites, not statistically different from $7.2 \mu \mathrm{M}$ obtained from the studies with a fixed amount of $\left[{ }^{125} \mathrm{I}\right] \mathrm{T}_{3}$ and varying amiodarone concentrations. Increasing concentrations of $T_{3}$ reversed amiodarone's effect on $T_{3}$ binding, characteristic of a competitive binding inhibitor. The data are redrawn as a Lineweaver-Burk plot in Fig. $2 B$. The slopes $( \pm 95 \%$ C.I.) were $0.07 \pm 0.00$ and $0.13 \pm 0.00$ in the absence or presence of $10 \mu \mathrm{M}$ amiodarone, respectively. The $y$-intercepts did not differ significantly. They were ( \pm standard error of estimate) $6.6 \pm 0.2$ and $6.8 \pm 0.7$, respectively, indicative of competitive binding.

We next addressed the issue of whether amiodarone could compete with [ $\left.{ }^{125} \mathrm{I}\right] \mathrm{T}_{3}$ for thyroid hormone receptor binding when incubated with intact cells. The nuclear $T_{3}$ receptors in cultured rat pituitary tumor cells (GC and related sublines) have been well characterized (26). Both $T_{3}$ and amiodarone competed with $\left[{ }^{125} \mathrm{I}\right] \mathrm{T}_{3}$ for binding to the thyroid hormone receptor in intact GC cells (Table I). Because $2 \%$ serum was included in the incubations for these experiments, the free concentrations of drug or hormone present within the media may not be exactly equal to the concentration of drug or hormone added to the media. In addition, the free intracellular concentration cannot be easily determined. For these reasons it is more accurate to compare the $\mathrm{EC}_{50}$ values for the blockade of receptor binding and the blockade of receptor function. Competition binding isotherms determined in this system at $300 \mathrm{pM}\left[{ }^{125} \mathrm{I}_{\mathrm{T}} \mathrm{T}_{3}\right.$ displayed an $\mathrm{EC}_{50}$ value of $3.3 \mu \mathrm{M}$ for amiodarone (Table I). Since these numbers were in close agreement to those obtained with solubilized receptors, the effects of $2 \%$ serum were slight. Computer-derived $(15,16)$ slope constants (pseudo-Hill coefficients) were not significantly different than 1.0, suggesting a competitive interaction to a single class of sites for both $\mathrm{T}_{3}$ and amiodarone.

The effects of $T_{3}$ and amiodarone on cellular equilibrium levels of $\left[{ }^{125} \mathrm{I}\right] \mathrm{T}_{3}$ were examined in cultured GC cells (Fig. 3). Both competitors caused parallel, dose-dependent decreases in radioactivity in whole cells and cytosol. In addition, the maximum decrease in both cellular and cytosolic radioactivity was $\sim 45-50 \%$ in response to either competitor. This result is in contrast to those obtained from GC cell nuclei, where radioactivity decreased by $\sim 75$ and $95 \%$ in response to increasing concentrations of amiodarone and nonradioactive $T_{3}$, respectively.

Cultured GC cells were utilized to assess the effect of amiodarone on $T_{3}$ action. These cells respond to $T_{3}$ by increasing their synthesis of rat growth hormone ( $\mathrm{rGH}$ ) due to increases in rGH mRNA resulting from transcriptional activation of the growth hormone gene $(18,28)$. As shown in Fig. 4 $A$, amiodarone blocked the induction of rGH mRNA by 300 pM $\mathrm{T}_{3}$ as analyzed by RNA blot (Northern) analysis. In three experiments RNA was normalized by loading equal amounts ( 15 or $20 \mu \mathrm{g}$ ) of cytoplasmic RNA per lane, and equivalency of loading was verified by visualization of $18 \mathrm{~S}$ and 5S rRNA by ultraviolet shadowing. As a further control, RNA content was normalized to human gamma-actin mRNA in an additional experiment with identical results. Autoradiographs were analyzed by densitometry, and arbitrary densitometric units were used to construct amiodarone competition curves. Fig. $4 B$ (open circles) displays an amiodarone mRNA competition curve that represents a composite of four experiments. The $\mathrm{EC}_{50}$ for blockade of $\mathrm{GH}$ mRNA by amiodarone under these conditions was $3.1 \mu \mathrm{M}$, very similar to the $\mathrm{EC}_{50}$ for binding to the thyroid hormone receptor of these cells in the presence of $300 \mathrm{pM} \mathrm{T}_{3}(3.3 \mu \mathrm{M})$ and is consistent with the $K_{\mathrm{d}}$ for binding

Table I. Binding Affinities $\left(K_{\mathrm{d}}\right)$ of $T_{3}$ and Amiodarone to Solubilized Nuclear Receptors of Rat Liver, Brain, Pituitary Tumor Cells or in Intact Cultured Cells

\begin{tabular}{|c|c|c|c|c|}
\hline \multirow[t]{2}{*}{ Receptor source } & \multicolumn{2}{|c|}{ Triiodothyronine } & \multicolumn{2}{|c|}{ Amiodarone } \\
\hline & $K_{d}$ & $* b$ & $K_{\mathrm{d}}$ & $b$ \\
\hline Liver & $3.7 \pm 0.1 \times 10^{-10} \mathrm{M}$ & $1.0 \pm 0.1$ & $7.2 \pm 2.1 \times 10^{-6} \mathrm{M}$ & $0.9 \pm 0.1$ \\
\hline Brain & & & $13.7 \pm 1.6 \times 10^{-6} \mathrm{M}$ & $1.0 \pm 0.1$ \\
\hline \multirow[t]{2}{*}{ GC cell } & $5.6 \pm 1.7 \times 10^{-10} \mathrm{M}$ & & $1.6 \pm 0.2 \times 10^{-6} \mathrm{M}$ & $0.7 \pm 0.1$ \\
\hline & ${ }^{\ddagger} \mathrm{EC}_{50}$ & & $\mathrm{EC}_{50}$ & \\
\hline GC nuclear binding (intact cells) & $8.7 \pm 0.2 \times 10^{-10} \mathrm{M}$ & $1.0 \pm 0.1$ & $3.3 \pm 0.2 \times 10^{-6} \mathrm{M}$ & $0.9 \pm 0.4$ \\
\hline Cytoplasmic rGH mRNA accumulation & & & $3.1 \pm 0.3 \times 10^{-6} \mathrm{M}$ & $0.8 \pm 0.1$ \\
\hline
\end{tabular}

$K_{\mathrm{d}}$ values determined by competition binding studies and analyzed by weighted, nonlinear least squares regression with the aid of the Scatfit computer program $(15,16)$. Affinities derived from liver receptor preparations represent the weighted means from six experiments. Other values represent the mean of at least two experiments. $\left({ }^{*} b\right)$ slope factor. Determined with Allfit $(15,16)$. Values for " $b$ " did not differ significantly from 1.0, indicating that both competitors interact with a single class of binding sites. ${ }^{\ddagger}\left(\mathrm{EC}_{50}\right)$ concentration of agonist $\left(\mathrm{T}_{3}\right)$ or antagonist (amiodarone) needed to decrease binding of $\left[{ }^{125} \mathrm{I}\right] \mathrm{T}_{3}(300 \mathrm{pM})$ to $50 \%$ of maximum values. 


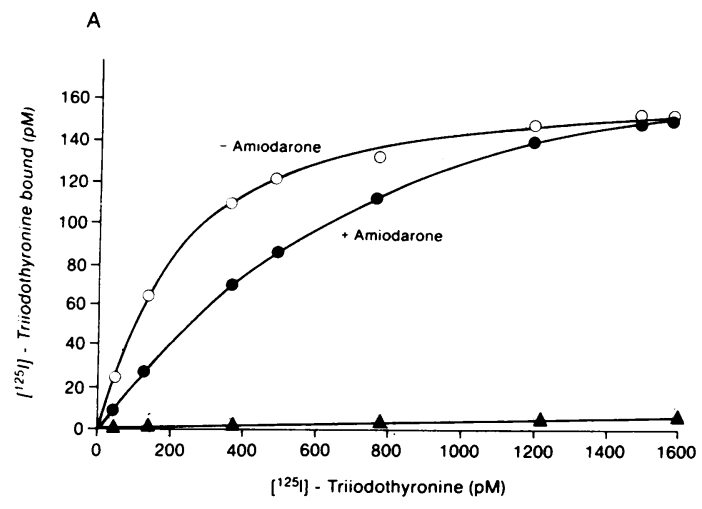

Figure 2. Effects of amiodarone on saturation binding of $T_{3}$ to soluble nuclear receptors. (a) Saturation binding isotherms: $150 \mathrm{pM}$ of soluble rat liver nuclear receptor $(3 \mathrm{pmol} / \mathrm{mg})$ was incubated with increasing amounts of $\left.{ }^{125} \mathrm{I}\right] \mathrm{T}_{3}$ in the absence $\left(K_{d}\right)$ and presence $\left(K_{d}\right)$ of inhibitor, and these values were used to determine a $K_{\mathrm{i}}$ for amiodarone. In these experiments more pure preparations of rat liver receptor were utilized than before. The following values were obtained from computer modeling: $K_{\mathrm{d}}=108 \mathrm{pM}, K_{\mathrm{d}}^{\prime}=224 \mathrm{pM}$, and $K_{\mathrm{i}}=9.3$ $\mu \mathrm{M}$. The lower line (closed triangles) indicates nonspecific binding (average of both curves), which represented $2-4 \%$ of total binding. Binding of $\left[{ }^{125} \mathrm{I}\right] \mathrm{T}_{3}$ in the presence of $1 \mu \mathrm{M}$ unlabeled $\mathrm{T}_{3}$ yields
B

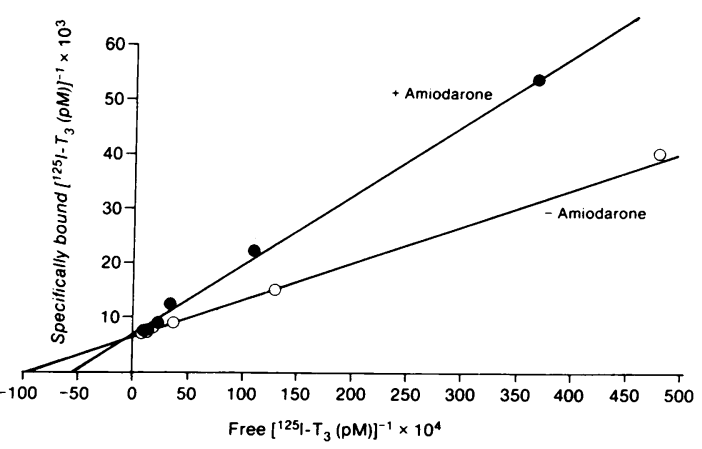

values for nonspecific binding (NSB). Separation of bound from free $T_{3}$ was achieved with G-25 Sephadex. (b) Lineweaver-Burk transformation of the data. The abscissa $(x)$ and ordinate $(y)$ represent the inverse of free $\mathrm{pM}\left[{ }^{125} \mathrm{I}\right] \mathrm{T}_{3}$ and $\mathrm{pM}\left[{ }^{125} \mathrm{I}\right] \mathrm{T}_{3}$ specifically bound, respectively. The slopes $(b)$ of the regressions in the absence and presence of amiodarone were $0.07 \pm 0.00$ and $0.13 \pm 0.00$, respectively (b $\pm 95 \%$ C.I.). The calculated $K_{\mathrm{i}}$ from these slopes using the less accurate graphical methods was $11.6 \mu \mathrm{M}$. The $y$-intercepts $(a)$ were $6.6 \pm 0.2$ and $6.8 \pm 0.7(\mathrm{a} \pm \mathrm{SEE})$, respectively, indicating that maximum binding did not differ in the absence or presence of amiodarone. $r^{2}=0.99$ for each regression line. to $\mathrm{GC}$ cell solubilized receptor $(1.6 \mu \mathrm{M})$. The binding and functional curves are essentially identical as illustrated by the open and closed circles in Fig. $4 \mathrm{~B}$. The slope factor of the composite curve did not differ significantly from 1.0, again suggesting that amiodarone's effects on rGH mRNA are directly mediated by its interaction with a single class of nuclear receptor binding sites (see Table I).

Since amiodarone displayed competitive binding to solubilized $T_{3}$ receptors (Fig. 2), we tested whether its inhibitory effects on rGH mRNA could be overcome by $T_{3}$. GC cells were deinduced $2 \mathrm{~d}$, then treated with $3.2 \mu \mathrm{M}$ amiodarone plus varying concentrations of $\mathrm{L}-\mathrm{T}_{3}$. After $24 \mathrm{~h}$ of culture, total cellular mRNA was quantified as described previously. In the absence of $\mathrm{T}_{3}$, amiodarone produced no effect on rGH mRNA (Fig. 5). GC cells exposed to $300 \mathrm{pM} \mathrm{T}_{3}$ in the absence of amiodarone had rGH mRNA levels about threefold greater than those in untreated cells, while amiodarone caused a reduction in mRNA levels under these conditions. Fig. 5 also demonstrates that a saturating dose of $T_{3}(5 \mathrm{nM})$ was able to overcome the inhibitory effects of amiodarone.

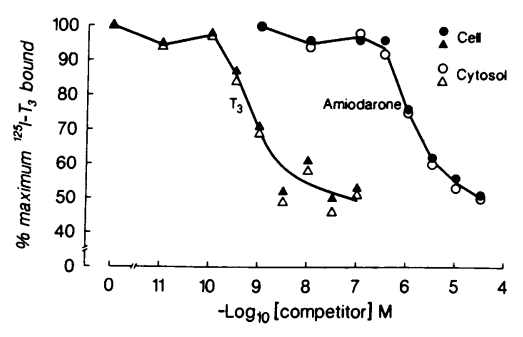

Figure 3. Effects of $\mathrm{T}_{3}$ and amiodarone on the levels of $\left[{ }^{125} \mathrm{I}\right] \mathrm{T}_{3}$ in whole GC cells and cytosol. GC cells $\left(2 \times 10^{6}\right)$ $\mathrm{ml}$ ) were incubated for $3 \mathrm{~h}$ in the presence of $300 \mathrm{pM}\left[{ }^{125} \mathrm{I}\right] \mathrm{T}_{3}$ plus increasing concentrations of either nonradioactive $\mathrm{T}_{3}$ or amiodarone (see Methods). Maximum cytosolic radioactivity was 95\% of whole cell radioactivity.

\section{Discussion}

These results are consistent with the concept that amiodarone acts as an antagonist to thyroid hormone action. This conclusion is supported by our observation that amiodarone $(a)$ binds to thyroid hormone receptors from a variety of tissues and $(b)$ inhibits $T_{3}$-induced increases in growth hormone mRNA levels in GC cells in a similar dose-dependent manner.

Previous binding studies utilizing amiodarone have yielded conflicting results. For example, an abstract by Wiersinga and Broenik (29) reported that amiodarone acts as a competitive inhibitor to $T_{3}$ binding in solubilized rat liver nuclear receptors. However, a more recent study (30) reported that amiodarone possessed no competitor activity in solubilized rat liver receptors. In cell culture studies, amiodarone did not inhibit hormone binding to rat hepatic nuclei (31) or to nuclei from cultured human fibroblasts (32), whereas it did compete for $\left[{ }^{125} \mathrm{I} \mathrm{T}_{3}\right.$ binding to isolated rat anterior pituitary nuclei $(8)$. The reason for this disparity is unknown. However, potentially important methodological differences exist among our studies. For example, two of the groups reporting negative results (30, 32) prepared amiodarone stocks from powder. We have found that amiodarone prepared in this way may gradually go out of solution, especially under tissue culture conditions. It is noteworthy that liquid amiodarone is supplied in a vehicle containing both benzyl alcohol and detergent (Tween 80 ), which may be essential for its solubility under assay conditions (see Methods for exact formulation). In addition, three of the groups reporting negative results (references 30-32) used ethanol as their diluent, whereas we used $1 \mathrm{mM} \mathrm{HCl}$. Finally, one group (32) utilized glass tubes for their culture experiments. Our experience indicates that amiodarone adheres to glass (see Methods).

Previous functional studies have suggested that amiodarone exhibits thyroid hormone antagonist-like effects. In physiologic studies, for example, amiodarone administration caused 


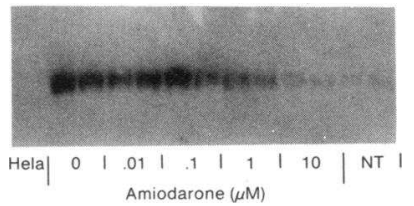

B

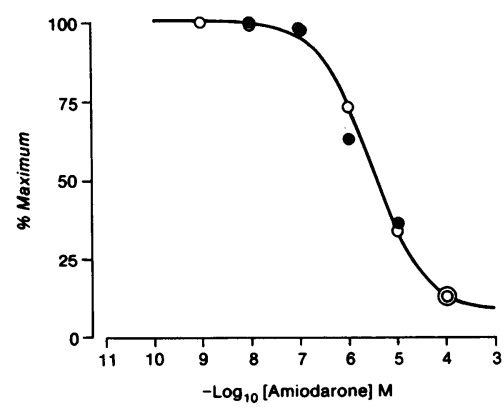

Figure 4. Effects of amiodarone on accumulation of $\mathrm{rGH}$ mRNA and on binding by $T_{3}$ to nuclear fractions of cultured GC cells. $(A)$ Autoradiogram of a representative Northern blot of rGH mRNA from GC cell cytoplasm. GC cells were plated at 2-4 $\times 10^{6}$ cells $/ 100 \mathrm{~mm}$ tissue culture dish (Falcon) and then deinduced as described in Methods. After $4 \mathrm{~d}$ of deinduction, cells were cultured for an additional $2 \mathrm{~d}$ in the presence of stripped media

containing (1) $300 \mathrm{pM} \mathrm{T}$ plus one of the following concentrations of amiodarone: $0,10 \mathrm{nM}, 100 \mathrm{nM}, 1 \mu \mathrm{M}$ or $10 \mu \mathrm{M}$; or (2) no additional treatment (NT). (B) (Open circles) composite mRNA response curve constructed from four amiodarone experiments with cultured GC cells. After treatment with $T_{3}$ and graded doses of amiodarone, cytoplasmic RNA was prepared and analyzed by Northern hybridization as described in Methods. After hybridization, blots were autoradiographed and analyzed using a Zeineh scanning densitometer. Arbitrary density units were used to construct competition curves and to derive $\mathrm{EC}_{50}$ values and slope factors for amiodarone's effect on rGH mRNA accumulation $(15,16)$. The " $100 \%$ " point on the curve represents data from cells treated with $300 \mathrm{pM} \mathrm{T}_{3}$ without amiodarone. The circled point represents data from nontreated cells. (Closed circles) amiodarone inhibition of binding of $\left.{ }^{125} \mathrm{I}\right] \mathrm{T}_{3}$ to nuclei of intact GC cells.

increases in basal TSH release (7), decreases in malic enzyme and $\alpha$-glycerol-phosphate dehydrogenase in rat liver (33), decreased rat serum triglycerides (34), and decreased cardiac myosin activity, an enzyme that is known to be induced by thyroid hormone (35). In cell culture studies amiodarone reduced $\mathrm{T}_{3}$-induced increases in $\left[{ }^{3} \mathrm{H}\right]$ thymidine incorporation into $\mathrm{GH}_{3}$ cells (36) and increased TSH release from cultured rat anterior pituitary cells (8).

Franklyn et al. (37) observed conflicting effects of in vivo administered amiodarone on mRNA levels for $T_{3}$-responsive

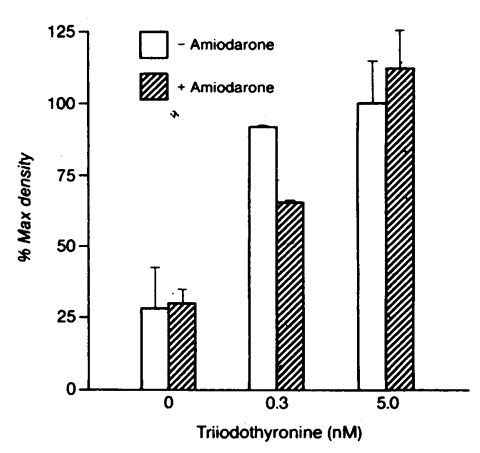

Figure 5. Effects of amiodarone plus increasing concentrations of $\mathrm{T}_{3}$ on $\mathrm{rGH}$ mRNA accumulation in cultured GC cells. GC cells were deinduced $2 \mathrm{~d}$, then incubated in the presence of $3.2 \mu \mathrm{M}$ amiodarone plus increasing concentrations of $T_{3}$. Total cellular mRNA was analyzed by hybridization to the $\mathrm{rGH}$ or actin cDNAs (see Methods), autoradio-

graphed and quantitated by scanning multiple exposures. Results are normalized to $\gamma$-actin. Data are expressed as percent maximum densitometry units. The bars indicate the mean \pm range of two determinations. genes in rats. Thus, amiodarone caused increases in pituitary TSH $\alpha$ and $\beta$ subunit mRNAs, consistent with a direct antagonistic effect of amiodarone to thyroid hormone action at the receptor level. However, no effect was observed on rGH mRNA levels. It is surprising that in hypothyroid rats, amiodarone exhibited $T_{3}$ agonist-like activity, causing decreased levels of TSH mRNA and increases in rGH mRNA. The reason for these disparate results was not fully resolved by the authors. However, hormonal interactions in vivo are much more complex than those observed under cell culture conditions, and comparisons between these approaches must be made with caution. Nevertheless, in our cell culture studies, we observed no evidence for $T_{3}$ agonist-like effects of amiodarone. Under "hypothyroid" cell culture conditions, amiodarone produced no significant effect on rGH mRNA.

Prolonged ( $24 \mathrm{~h}$ or more) incubation of GC cells with $10^{-4}$ $M$ amiodarone, an amount that precipitates under culture conditions, reduced cell viability, which is an effect observed by others (36). However, decreases in rGH mRNA levels are not due to nonspecific effects of amiodarone since the antagonist was selective for $\mathrm{rGH}$ mRNA, and amiodarone at $10 \mu \mathrm{M}$ was unable to reduce rGH mRNA levels below baseline. Further experiments revealed that $5 \mathrm{nM} \mathrm{T}_{3}$ abolished the effects of amiodarone (Fig. 5). Finally, when amiodarone-treated cells are cultured in fresh media containing FCS, growth and rGH mRNA levels are restored (data not shown); an effect that is to be expected of a hormone antagonist (38).

Cellular and nuclear transport systems for thyroid hormones have been described, but studies have not yielded consistent data in the hands of all investigators. A nonsaturable, stereo-specific, $T_{3}$ uptake system has been described for rat hepatocytes by Oppenheimer (39). Krenning et al. have described a different low affinity, energy-dependent transport system for $T_{3}$ in rat hepatocytes that, in contrast to that described by Oppenheimer, appears to be inhibited by $L-T_{3}(40)$ or, when tested at a single dosage and time point, by amiodarone (41). In addition, rat pituitary tumor $\left(\mathrm{GH}_{1}\right)$ cells are able to concentrate $T_{3}$ across the cellular and especially the nuclear membranes (42) and transport into $\mathrm{GH}_{1}$ cells appears to be saturable, similar to the effects observed in the present study.

In any case, it might be predicted that a substance that recognizes the nuclear thyroid hormone receptor would interact at other hormone binding sites on or within the cell. Therefore, we asked whether amiodarone altered $\left[{ }^{125} \mathrm{I}\right] \mathrm{T}_{3}$ levels in the nonnuclear compartment of GC cells. In our study, both $\mathrm{T}_{3}$ and amiodarone caused a maximum 45 to $50 \%$ reduction in total cellular or cytosolic radioactivity in GC cells when assayed at equilibrium with $300 \mathrm{pM}\left[{ }^{125} \mathrm{I}\right] \mathrm{T}_{3}$. However, a relatively greater reduction in nuclear counts was seen with both amiodarone $(75 \%)$ and $\mathrm{L}-\mathrm{T}_{3}(95 \%)$. If the competitors were acting solely to inhibit $\left.{ }^{125} \mathrm{I}\right] \mathrm{T}_{3}$ transport, exactly parallel relative decreases in cellular, cytosolic and nuclear radioactivity would be observed. We also found that the affinity of amiodarone for binding to the thyroid hormone receptor is very similar in solubilized receptor from GC cell nuclei and in nuclear fractions from intact GC cells (Table I), a result that would be unexpected if amiodarone's blockade of the nuclear thyroid hormone receptor were occurring by different mechanisms in the intact cells and solubilized preparations. In addition, the affinity of $T_{3}$ for its receptor is essentially the same in whole cells and in solubilized nuclear extracts. Finally, the slope factors $(b)$ for amiodarone's interactions with thyroid 
hormone receptor preparations from both solubilized tissues and intact cells do not differ from 1.0, consistent with the interpretation that amiodarone interacts with a single class of binding sites in the receptor preparations. Thus, we conclude that both competitors affect equilibrium levels of nonnuclear $\left[{ }^{125} \mathrm{I}\right] \mathrm{T}_{3}$ in a parallel manner by altering hormone transport across the cell surface, but both $\mathrm{T}_{3}$ and amiodarone are likely to have additional direct effects on the nuclear thyroid hormone receptor. Indirect support for a nuclear site of action for amiodarone is found in a study by Hostetler et al. (43), who observed that the cell nucleus contained most of the amiodarone recovered from fractionated lung proteins of drug-treated rats.

Our findings raise the question as to whether the cardiac effects of amiodarone could be due to direct interactions with the $T_{3}$ receptor. For example, chronic amiodarone treatment causes decreases in both growth rate and cardiac weight in rabbits, and these changes are reversible by $T_{4}$ administration (44). In rats, thyroidectomy causes a reduction in heart weight, cardiac $\mathrm{CO}_{2}$ production and myosin $\mathrm{Ca}^{2+}$-ATPase activity. Parallel, although less pronounced, changes are induced by amiodarone. Notably, the effects of both thyroidectomy as well as amiodarone treatment are reversible by thyroid hormone (35).

Serum levels of amiodarone in humans and rats receiving long-term treatment vary from $\sim 1$ to $6 \mu \mathrm{M}(45,46)$, which is in the range of $K_{d}$ values observed in this study. Perhaps of more importance, however, is the fact that amiodarone is concentrated preferentially in certain tissues over time, and it could conceivably accumulate at levels that would allow it to work as a full antagonist $(5,45)$. For example, necropsy studies have revealed that liver, lung, and heart preferentially accumulate extraordinarily high concentrations of the drug, containing between $2,600 \mathrm{mg} / \mathrm{kg}$ and $200 \mathrm{mg} / \mathrm{kg}$ of amiodarone and its metabolite desethylamiodarone; this is far more (40- to 3.5-fold) than that contained by brain or thyroid gland (60 $\mathrm{mg} / \mathrm{kg}$ ) (46). Pituitary accumulation is unknown. Therefore amiodarone might produce variable in vivo effects on differing tissues based on varying concentrations within the tissue. This could explain why obvious hypothyroidism does not occur in most amiodarone-treated patients, since tissue levels depend on individual patient idiosyncrasy and variation of dose and duration of therapy. Similarly, because of the weak affinity of the drug and its varying tissue absorption, some patients even have symptoms of thyrotoxicosis when iodine induced hyperthyroidism overwhelms the antagonistic properties of amiodarone.

Numerous structure-activity studies have suggested the necessity of bulky iodine or propyl substituents on the outer ring $3^{\prime}$ position and the presence of a carboxylic acid group for effective receptor binding and agonist function $(2,47)$. Amiodarone possesses neither of these moieties, and indeed comparison of the two-dimensional chemical structures reveals no obvious structural similarities between the drugs. To explore a possible structural similarity between $T_{3}$ and amiodarone, extended conformation molecular models, using standard data sets, were constructed with the MIDAS program at the Computer Graphics Laboratory, University of California, San Francisco (Fig. 6). Fig. $6 \mathrm{~A}$ displays triiodothyronine (left) and amiodarone (right), each with computer-generated van der Waals surfaces displayed around their respective iodine atoms. When the diiodophenyl rings of each compound are juxta-
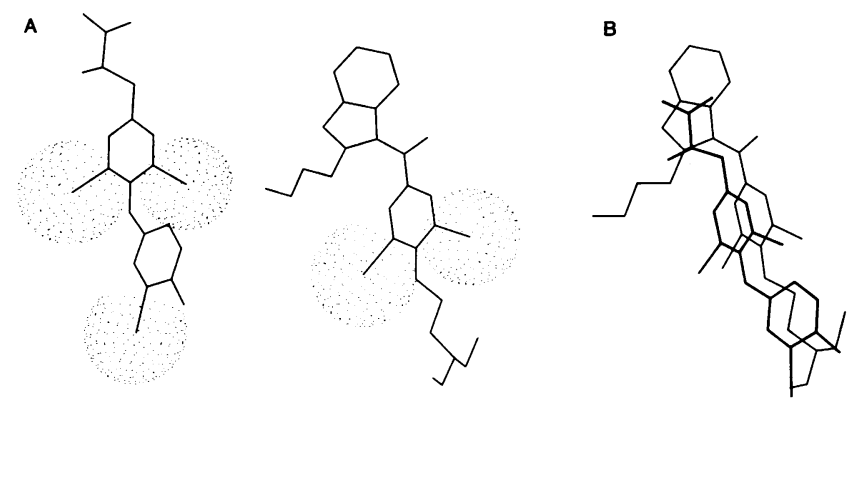

C

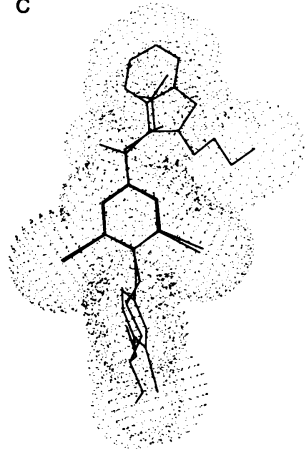

D

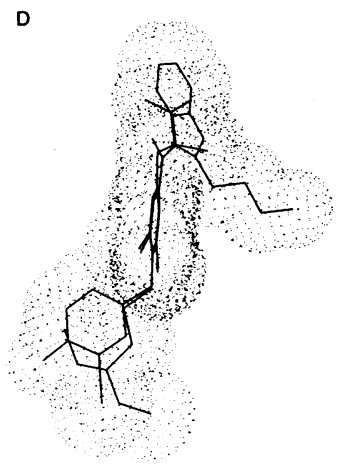

Figure 6. Computer-generated models of $\mathrm{T}_{3}$ and amiodarone. $(A)$ van der Waals forces associated with the iodine atoms are illustrated for each molecule. $T_{3}$ is on the left, amiodarone on the right. $(B) \mathrm{Hy}$ pothetical alignment of molecules along "vertical" axes. $(C)$ Superimposition of phenol rings showing similarity of spacefilling by surface van der Waals forces. $(D)$ As in $c$, with $90^{\circ}$ rotation along vertical axes. Slight changes in amiodarone torsional angles would increase the similarity of the superimposition of amiodarone and the "lower" ring of triiodothyronine.

posed a remarkable degree of similarity can be seen along their entire "vertical" axes (Fig. $6 \mathrm{~B}$ ). Complete superimposition of the diiodophenyl rings leads to the structures shown in Fig. $6 C$ and, rotated $90^{\circ}$ along their "vertical" axes, Fig. $6 \mathrm{D}$. A striking homology exists between the van der Waals surfaces of each drug. The "lower" portion of the superimposed structures containing the inner and outer rings of triiodothyronine displays the greatest degree of similarity, and has been proposed by Jorgensen (48) to interact with the receptor protein. The "upper" portion of the structures, containing the benzofuran and its 2-butyl adduct, is most dissimilar, suggesting a structural basis for antagonism.

The utility of amiodarone as a thyroid hormone antagonist is limited for several reasons. First, the drug has a low affinity for the thyroid hormone receptor. Second, numerous amiodarone-induced toxic side effects have been reported $(4,5)$. Third, amiodarone probably exerts effects that are not related to thyroid hormone activity. For example, amiodarone inhibits in vitro phospholipase $A_{1}$ production in rat alveolar macrophages, J-774 macrophages and rat liver (43) when used at concentrations 5-10 times greater than that required to inhibit $\mathrm{T}_{3}$ receptor binding by $50 \%$. Finally, the drug has a long half-life and accumulates extensively in tissues; this could hinder the ability to regulate the actions of the drug.

Nevertheless, this study demonstrates that amiodarone interacts directly with the nuclear thyroid hormone receptor, 
and that it antagonizes the effects of thyroid hormone on $\mathrm{rGH}$ message. In addition, it indicates that other amiodarone-like derivatives have the potential to be of considerable practical value both clinically as cardiotherapeutic drugs, and as tools for further investigating the molecular mechanisms of thyroid hormone action.

\section{Acknowledgments}

We wish to acknowledge the technical assistance of Jim Apriletti and Shiro Horita. Computer modeling was performed at the Computer Graphics Laboratory (UCSF) by Teri Klein and George Seibel. The pRGH- 1 rat cDNA and the pHF1 human $\gamma$-actin cDNA were gifts from Drs. Norman Eberhardt and Brian West, respectively, U.C. San Francisco. Powdered amiodarone- $\mathrm{HCl}$ was a gift from Sanofi Chemicals (Montpellier). Drs. A. DeLean and R. Lefkowitz generously provided the Scatfit and Allfit computer programs.

Supported by National Institutes of Health grants INRSA AM-07610-02 (to Dr. Norman) and AM-01329 (to Dr. Lavin).

\section{References}

1. Gilman, A. G., and L. S. Goodman, editors. 1985. Pharmacological Basis of Therapeutics. 7th ed. MacMillan, New York.

2. Jorgensen, E. C. 1978. Thyroid hormones and analogs. II. Structure-activity relationships. In Hormonal Proteins and Peptides. C. H. Li editor. Vol. VI. Academic Press, Inc., New York. 107-204.

3. Somack, R., T. A. Andrea, and E. C. Jorgensen. 1982. Thyroid hormone binding to human serum prealbumin and rat liver nuclear receptor: kinetics, contribution of the hormone phenolic hydroxyl group, and accommodation of hormone side-chain bulk. Biochemistry. 21:163-170.

4. McKenna, W. J., and E. Rowland, editors. 1986. The place of amiodarone in cardiology today. Br. J. Clin. Proc. 40(Suppl.):44.

5. Mason, J. W. 1987. Amiodarone. N. Engl. J. Med. 316:455-466.

6. Burger, A., D. Dinichert, P. Nicod, M. Jenny, T. LemarchandBeraud, and M. B. Vallotton. 1976. Effect of amiodarone on serum triiodothyronine, reverse triiodothyronine, thyroxin, and thyrotropin. J. Clin. Invest. 58:255-259.

7. Melmed, S., D. Nademanee, A. W. Reed, J. A. Hendrickson, B. N. Singh, and J. M. Hershman. 1981. Hyperthyroxinemia with bradycardia and normal thyrotropin secretion after chronic amiodarone administration. J. Clin. Endocrinol. Metab. 53:997-1001.

8. Franklyn, J. A., J. R. Davis, M. D. Gammage, W. A. Littler, D. B. Ramsden, and M. C. Sheppard. 1985. Amiodarone and thyroid hormone action. Clin. Endocrinol. 22:257-264.

9. Samuels, H. H., F. Stanley, and J. Casanova. 1979. Depletion of L-3,5, 3'-triiodothyronine and L-thyroxine in euthyroid calf serum for use in cell culture studies of the action of thyroid hormone. Endocrinology. 105:80-85.

10. Apriletti, J. W., J. D. Baxter, and T. N. Lavin. 1988. Large scale purification of the nuclear thyroid hormone receptor from rat liver and sequence-specific binding of the receptor to DNA. J. Biol. Chem. 263:9409-9417.

11. Schwartz, H. L., and J. H. Oppenheimer. 1978. Ontogenesis of $3,5,3^{\prime}$-triiodothyronine receptors in neonatal rat brain: dissociation between receptor concentration and stimulation of oxygen consumption by 3,5,3'-triiodothyronine. Endocrinology. 103:943-948.

12. Bauer, R. F., L. O. Arthur, and D. L. Fine. 1976. Propagation of mouse mammary tumor cell lines and production of mouse mammary tumor virus in a serum-free medium. In Vitro. 12:558-563.

13. Samuels, H., and J. S. Tsai. 1973. Thyroid hormone action in cell culture: demonstration of nuclear receptors in intact cells and isolated nuclei. Proc. Natl. Acad. Sci. USA. 70:3488-3492.

14. Burton, K. 1956. A study of the conditions and mechanism of the diphenylamine reaction for the colorimetric estimation of deoxyribonucleic acid. Biochem. J. 62:315-323.

15. DeLean, A., P. J. Munson, and D. Rodbard. 1978. Simultaneous analysis of families of sigmoidal curves: application to bioassay, radioligand assay, and physiological dose-response curves. Am. J. Physiol. 235:E97-E102.

16. DeLean, A., A. A. Hancock, and R. J. Lefkowitz. 1982. Validation and statistical analysis of a computer modeling method for quantitative analysis of radioligand binding data for mixtures of pharmacological receptor subtypes. Mol. Pharmacol. 21:5-16.

17. Martial, J. A., P. H. Seeburg, D. Guenzi, H. M. Goodman, and J. D. Baxter. 1977. Regulation of growth hormone gene expression: synergistic effects of thyroid and glucocorticoid hormones. Proc. Natl. Acad. Sci. USA. 74:4293-4295.

18. Yaffe, B. M., and H. H. Samuels. 1984. Hormonal regulation of the growth hormone gene. J. Biol. Chem. 259:6284-6291.

19. Favaloro, J., R. Treisman, and R. Kamen. 1980. Transcription maps of polyoma virus-specific RNA: analysis by two-dimensional nuclease S1 gel mapping. Methods Enzymol. 65:718-749.

20. Maniatis, T., E. F. Fritsch, and J. Sambrook. 1982. Molecular Cloning. A laboratory manual. Cold Spring Harbor Laboratory. Cold Spring Harbor, New York. p. 196.

21. Carmichael, G. G., and G. K. McMaster. 1980. The analysis of nucleic acids in gels using glyoxal and acridine orange. Methods Enzymol. 65:380-391.

22. Seeburg, P. H., J. Shine, J. A. Martial, J. D. Baxter, and H. M. Goodman. 1977. Nucleotide sequence and amplification in bacteria of structural gene for rat growth hormone. Nature (Lond.). 270:486-494.

23. Gunning, P., P. Ponte, H. Okayama, J. Engel, H. Blau, and L. Kedes. 1983. Isolation and characterization of full-length cDNA clones for human $\alpha-, \beta$-, and $\gamma$-actin mRNAs: skeletal but not cytoplasmic actins have an amino-terminal cysteine that is subsequently removed. Mol. Cell. Biol. 3:787-795.

24. Rigby, P. W. J., M. Dieckmann, C. Rhodes, and C. P. Berg. 1977. Labeling deoxyribonucleic acid to high specific activity in vitro by nick translation with DNA polymerase I. J. Mol. Biol. 113:237251 .

25. Apriletti, J. W., Y. David-Inouye, J. D. Baxter, and N. L. Eberhardt. 1983. Physicochemical characterization of the intranuclear thyroid hormone receptor. In The Molecular Basis of Thyroid Hormone Action. J. H. Oppenheimer and H. H. Samuels, editors. Academic Press, New York. 67-97.

26. Samuels, H. H. 1983. Identification and characterization of thyroid hormone receptors and action using cell culture techniques. In The Molecular Basis of Thyroid Hormone Action. J. H. Oppenheimer, and H. H. Samuels, editors. Academic Press, Inc., New York. 36-65.

27. Sanofi Research. 1983. Amiodarone Solubility. Document No. 67.200.84. Sanofi Pharmaceuticals, Montpellier, France.

28. Spindler, S. R., S. H. Mellon, and J. D. Baxter. 1982. Growth hormone gene transcription is regulated by thyroid and glucocorticoid hormones in cultured rat pituitary tumor cells. J. Biol. Chem. 257:11627-11632.

29. Wiersinga, W. M., and M. M. Broenik. 1983. In-vitro inhibition of nuclear thyroid hormone binding by amiodarone and desethylamiodarone in rat liver and cardiac muscle. Am. Thyroid. Assoc. Vol. 00:36. (Abstr.)

30. Latham, K. R., D. F. Sellitti, and R. E. Goldstein. 1987. Interaction of amiodarone and desethylamiodarone with solubilized nuclear thyroid hormone receptors. J. Am. Coll. Cardiol. 9;872-876.

31. Sogol, P. B., J. M. Hershman, A. W. Reed, and W. H. Dillman. 1983. The effects of amiodarone on serum thyroid hormones and hepatic thyroxine 5'-monodeiodination in rats. Endocrinology. 113:1464-1469.

32. Eil, C., and R. Y. Chestnut. 1985. The effects of radiographic contrast agents and other compounds on the nuclear binding of $\mathrm{L}$ $\left.{ }^{[25} \mathrm{I}\right]$ triiodothyronine in dispersed human skin fibroblasts. J. Clin. Endocrinol. Metab. 60:548-552.

33. Pekary, A. E., J. M. Hershman, A. W. Reed, R. Kannon, and 
Y.-S. Wang. 1986. Amiodarone inhibits $T_{4}$ to $T_{3}$ conversion and $\alpha$ glycerophosphate dehydrogenase and malic enzyme levels in rat liver. Horm. Metab. Res. 18:114-118.

34. Kasim, S. E., N. Bagchi, T. R. Brown, and S. Khilnani. 1987. Effect of amiodarone on serum lipids, lipoprotein lipase, and hepatic triglyceride lipase. Endocrinology. 120:1991-1995.

35. Bagchi, N., T. R. Brown, D. Schneider, and S. K. Banerjee. 1987. Effects of amiodarone on rat heart myosin isoenzymes. Circ. Res. 60:621-625.

36. Goldfine, I. D., B. Maddux, and K. A. Woeber. 1982. Effect of amiodarone on L-triiodothyronine stimulation of $\left[{ }^{3} \mathrm{H}\right]$ thymidine incorporation into $\mathrm{GH}_{3}$ cells. $J$. Endocrinol. Invest. 5:165-168.

37. Franklyn, J. A., M. D. Gammage, and M. C. Sheppard. 1987. Amiodarone and thyroid hormone effects on anterior pituitary hormone gene expression. Clin. Endocrinol. 27:373-382.

38. DeFesi, C. R., E. C. Fels, and M. I. Surks. 1985. L-Triiodothyronine $\left(T_{3}\right)$ stimulates growth of cultured GC cells by action early in the $G_{1}$ period: evidence for mediation by the nuclear $T_{3}$ receptor. Endocrinology. 116:2062-2069.

39. Mooradian, A. D., H. L. Schwartz, C. N. Mariash, and J. H. Oppenheimer. 1985. Transcellular and transnuclear transport of 3,5,3'-triiodothyronine in isolated hepatocytes. Endocrinology. 117:2449-2456.

40. Krenning, E. P., R. Docter, H. F. Bernard, T. J. Visser, and G. Hennemann. 1980. Regulation of the active transport of 3,3',5-triiodothyronine $\left(\mathrm{T}_{3}\right)$ into primary cultured rat hepatocytes by ATP. FEBS (Fed. Eur. Biochem. Soc.) Lett. 119:279-282.
41. Krenning, E. P., R. Docter, H. F. Bernard, T. J. Visser, and G. Hennemann. 1982. Decreased transport of thyroxine $\left(T_{4}\right), 3,3^{\prime}, 5^{\prime}$-triiodothyronine $\left(\mathrm{T}_{3}\right)$ and 3,3',5'-triiodothyronine $\left(\mathrm{rT}_{3}\right)$ into rat hepatocytes in primary culture due to a decrease of cellular ATP content and various drugs. FEBS (Fed. Eur. Biochem. Soc.) Lett. 140:229-233.

42. Freake, H. C., A. D. Mooradian, H. L. Schwartz, and J. H. Oppenheimer. 1986. Stereospecific transport of triiodothyronine to cytoplasm and nucleus in GH1 cells. Mol. Cell. Endocrinol. 44:25-35.

43. Hostetler, K. Y., M. J. Reasor, E. R. Walker, P. J. Yazaki, and B. W. Frazee. 1986. Role of phospholipase A inhibition in amiodarone pulmonary toxicity in rats. Biochim. Biophys. Acta. 875:400-405.

44. Singh, B. N., and E. M. Vaughan Williams. 1970. The effect of amiodarone, a new anti-anginal drug, on cardiac muscle. Br. J. Pharmacol. 39:657-667.

45. Plomp, T. A., W. M. Wiersinga, and R. A. A. Maes. 1985. Tissue distribution of amiodarone and desethyl-amiodarone in rats after multiple administration of various amiodarone dosages. Drug Res. 35:122-129.

46. Holt, D. W., G. T. Tucker, P. R. Jackson, and G. C. A. Storey. 1983. Amiodarone pharmacokinetics. Am. Heart J. 106:840-847.

47. Cody, V. 1980. Thyroid hormone interactions: molecular conformation, protein binding, and hormone action. Endocr. Rev. 1:140166.

48. Dietrich, S. W., M. B. Bolger, P. A. Kollman, and E. C. Jorgensen. 1977. Thyroxine analogues. 23. Quantitative structure-activity correlation studies of in vivo and in vitro thyromimetic activities. $J$. Med. Chem. 20:863-880. 